\title{
Substituting Wheat Flour using Banana Peel Flour to Enhance the Nutritional Characteristics of Brownies
}

\author{
C. Divya, Ammiti Sheeba Rani, M. Tito Anand, N. Baskaran and R. Vidyalakshmi* \\ Indian Institute of Food Processing Technology, Thanjavur, Tamil Nadu, India \\ *Corresponding author
}

\section{A B S T R A C T}

Key w o r d s
Mysore AAB peel,
Brownies, Wheat
flour and Baking
and yield

\begin{abstract}
Bananas are consumed globally in larger quantities where the peel contributes for about one third of the fruit weight, is often discarded as waste. This by-product is rich in functional compounds, dietary fiber compared to pulp. In this study Mysore AAB banana peel flour (BPF) generally called poovan was used for the development of brownie. Six formulations were developed: $1.100 \%$ wheat flour (Control), 2. 10\% peel flour with $90 \%$ wheat flour (F1), 3. 20\% peel flour with $80 \%$ wheat flour (F2), $4.30 \%$ peel flour with $70 \%$ wheat flour (F3), 5. $40 \%$ peel flour with $60 \%$ wheat flour (F4) and $6.50 \%$ peel flour with $50 \%$ wheat flour (F5). F1 and F2 have greater yield compared to other formulations and also lower loss occurred during baking. Besides, brownies supplemented with peel flour have enriched with nutrients and the sensory attributes of brownies were significantly different from the control when the peel flour rate increased. Both formulations scored higher in all attributes like flavor, mouth feel, after taste and overall acceptability. Therefore, addition of peel flour has an impact on the physical, chemical and sensory attributes of the products.
\end{abstract}

\section{Introduction}

Growth in the agro-food industries concerned with fruit processing is rising every day. This rise in productivity has also increased agricultural and industrial waste globally. Banana a tropical fruit commonly termed for the range of species or hybrids in the genus Musa of the family Musaceae. Musa acuminata and Musa balbisiana, native to Southeast Asia, have produced almost all of the recognized edible-fruit cultivars (Zhang $e t$ al., 2009). It is broadly consumed all over the world and economically marketed. According to (FAO, 2003) bananas are cultivated in higher quantities in tropical and subtropical areas with the world production of Musa estimated at 102 million MT in 2003.Furthermore, it is considered among the world's major food crop including rice, wheat and maize (FAOSTAT 2017). Pulp of the banana is mainly considered as an edible one which is rich in nutrients where the peel covers $40 \%$ of the fruit is generally regarded as waste (Amini Khoozani et al., 2019). However, food processing industries mainly focused on the banana pulp where the leaves, pseudo stem and peel are discarded as waste. 
Higher amount of these waste given arise a new conundrum during disposal (Pathak et al., 2016). The extract obtained from the banana peel is regarded as nontoxic and several authors investigated its effect on food products by incorporating cereal bars from BPF (Carvalho \& Conti-Silva, 2018). Studies showed that BPF have different forms of starch, cellulose and bioactive compounds which can be extracted and isolated to use as an element for enrichment of food(Kitts, 1994). These bioactive compounds which present in smaller quantities promotes probiotic growth and helps to prevents cardiovascular disease and cancer. Compared to pulp, banana peel is rich in soluble fibre pectin and can use as an additive (Lee et al., 2010). Besides, the protein, ash, starch and crude fibre of peel is higher than banana pulp and can use as a functional additive (Nasrin et $a l$. , 2015). In addition, the water holding capacity and swelling capacity of the BPF is high where the oil holding capacity is less. Following this, it also has the tendency to retard lipid oxidation. Hence it is suitable for the development of fried products to get a non-greasy sensation. Studies shows higher carotenoid content in peel than pulp where the gallocatechins content is profusely present in peel. In previous studies, numerous products had been developed by enrichment of BPF in various products like pasta, noodles and cakes. In current study, brownie a dessert item was chosen to be enriched with BPF to enhance its physicochemical and sensory properties.

Brownies are a kind of chocolate cake which can be fudgy or caky based on the consumer preferences. Preparation of brownies includes wheat flour, egg, fat, sugar and chocolate generally and have lesser nutritional value. Previous studies reported the addition of few value added ingredients and its impact in brownies. In (I et al., 2018) findings the substitution of sweet potato flour with different proportions of black cumin oil in brownies were analyzed, resulting in addition of $0.05 \%$ oil in the substituted flour got higher overall acceptability and the nutrients like protein, fat and ash were increased excluding the carbohydrate level. (Abreu et al., 2020) evaluated brownies incorporated with red mombin seed flour at various levels improved the nutrition properties like antioxidant, protein and ash also the physical properties.

Since substitution of BPF in brownies were not developed. This work aims to develop a standardized formulation of brownie from the freeze-dried peel flour of Mysore AAB (Poovan) to evaluate its addition in the formulation of the brownie.

\section{Materials and Methods}

\section{Sampling and Processing of Banana Peel Flour}

Mysore AAB was sampled from the super market in Thanjavur, India with the color index of 4 (Sandra et al., 2020). In the first instance the peel was removed from the pulp manually, washed with distilled water, and sliced. Banana slices were soaked in citric acid $(1 \mathrm{~g} / \mathrm{L})$ for 30 minutes and drained to inhibit browning (Arquelau et al., 2019). The peels were then dried in a batch type oven drier at $50^{\circ} \mathrm{C}$ for $24 \mathrm{hrs}$. Then they were grounded and sieved. Samples obtained was collected and stored in an air tight container for further analysis.

\section{Preparation of brownies}

Brownies were developed immediately after the preparation of flour, following a standard method with the addition of five different proportion of banana peel flour. Table 1 shows the ingredients used in the brownie preparation. 
Initially powdered sugar, egg and oil were homogenized using a whipper, next the chocolate and butter were melted using double boiling method and poured over the mixture. Eventually the dry ingredients like wheat flour, banana peel flour, cocoa powder and salt were added in to the mixture and homogenized until it resulted a uniform consistency where vanilla essence was added for flavor. Overall mixture was placed in an aluminum pans, previously coated with butter and baked in a pre-heated conventional oven at $180^{\circ} \mathrm{C}$ for 30 minutes. The brownie pieces were sliced and stored for further analysis after it reached the room temperature.

\section{Physicochemical properties of BPF}

\section{Yield factor and baking loss of the brownie}

Yield factor and baking loss was calculated by the following formula after measuring the batter weight and brownie weight.

Yield factor $=$ Batter weight $/$ Brownie weight (Moraes et al., 2010)

Baking loss $\%=$ Dry weight - Brownie weight / Brownie weight x 100 (Türker B, Savlak N, 2016)

\section{Water activity of brownie}

Water activity was determined using a \pm 0.001 sensitivity (Aqualab 4TE, USA) instrument. It was measured for all formulations by taking $1 \mathrm{~g}$ of flour for analysis.

\section{Colorimetric parameters}

The color properties of all brownie formulations (Kumar et al., 2019)were determined using Hunter Lab spectrophotometer. The results were expressed in $\mathrm{L}^{*}$ (black-white) $\mathrm{a}^{*}$ (red-green) and $b^{*}$ (yellow-blue).

\section{Determination of proximate analysis}

Using AOAC standard methods moisture, fat, protein, ash, and carbohydrate of the flour and the product were analysed (AOAC, 2016).

\section{Sensory analysis of brownies}

BPF substituted brownies with different formulations were analysed by an un-trained panel consists of 40 panelists of age under 20 and 35 years using a 9-point hedonic scale where 1 expressed as lack of sensation and higher point 9 expressed as higher sensation. The test was carried between 10 am to $12 \mathrm{pm}$ in the research laboratory of the institute. Each test has been made with $15 \mathrm{~g}$ of samples served in disposable plates (Theagarajan et al., 2019).

\section{Statistical analysis}

All experiments were conducted three times and the data was expressed in terms of mean \pm SD. Significant differences among the proportions were obtained by Tukey test with a significant level of $(p<0.05)$ and the oneway analysis of variance was conducted using SPSS statistical software 2.0.

\section{Results and Discussion}

\section{Yield factor and Baking loss of brownies}

The yield factor of the brownies prepared at different proportions are shown in Table 2.

Use of peel flour in brownie production affected the physical properties of brownies such as brownie volume and yield factor. Table 2. represented the yield factor and baking loss of the brownie. Addition of F1 and F2 of peel flour increased the yield factor of the brownie which was similar with control where the higher addition of peel flour acted inversely. This may be due to the water 
absorption capacity of the fibers present in the peel flour, which decrease the free water present in the dough (Silva et al., 2017) and subsequently reduces the loss of during baking thereby increase the yield factor of brownies. Weight of the brownie also increased during the incorporation of peel flour; this could be due to the fibre present in the peel flour helps to hold the air thereby increase the viscosity of the batter resulted in higher volume of the brownie. Baking loss of $\mathrm{F} 1$ and $\mathrm{F} 2$ formulated brownies was similar. F3, F4 and F5 of formulated brownies had less baking loss and completely varied from control. This lower rate of baking loss is due to the higher water holding capacity of the peel flour leads to higher water intake from the products and also it affects the quality characteristics of dough and final product's volume, and color (Mohamed et al., 2010).

Table.1 Different formulation of brownies prepared

\begin{tabular}{|l|c|c|c|c|c|c|}
\hline \multirow{2}{*}{ Ingredients } & \multicolumn{7}{|c|}{ Formulations } & F4 \\
\hline Wheat flour & Control & F1 & F2 & F3 & F4 & 50 \\
\hline Sugar & 100 & 90 & 80 & 70 & 60 & 125 \\
\hline Cocoa powder & 125 & 125 & 125 & 125 & 125 & 10 \\
\hline Chocolate & 10 & 10 & 10 & 10 & 10 & 100 \\
\hline Banana peel flour & 100 & 100 & 100 & 100 & 100 & 50 \\
\hline Oil & 0 & 10 & 20 & 30 & 40 & 7.5 \\
\hline Egg & 7.5 & 7.5 & 7.5 & 7.5 & 7.5 & 90 \\
\hline Fat & 90 & 90 & 90 & 90 & 90 & 69 \\
\hline
\end{tabular}

1. $100 \%$ wheat flour (Control), 2. $10 \%$ peel flour with $90 \%$ wheat flour(F1), 3. $20 \%$ peel flour with $80 \%$ wheat flour(F2), 4. 30\% peel flour with 70\% wheat flour(F3), 5. $40 \%$ peel flour with $60 \%$ wheat flour (F4) and $6.50 \%$ peel flour with $50 \%$ wheat flour (F5)

Table.2 Yield factor and baking loss $\%$ of brownies

\begin{tabular}{|l|c|c|c|c|c|c|}
\hline & Control & F1 & F2 & F3 & F4 & F5 \\
\hline Batter & 470 & 480 & 495 & 485 & 483 & 480 \\
\hline Brownie & 410 & 415 & 430 & 435 & 435 & 435 \\
\hline Yield factor & 1.14 & 1.15 & 1.15 & 1.11 & 1.11 & 1.10 \\
\hline Baking loss \% & 14.63 & 15.66 & 15.12 & 11.49 & 11.03 & 10.35 \\
\hline
\end{tabular}

Table.3 Color values of brownies

\begin{tabular}{|l|l|l|l|}
\hline Formulations & $\mathbf{L}^{*}$ & $\mathbf{a}^{*}$ & $\mathbf{b}^{*}$ \\
\hline Control & $23.35^{\mathrm{a}} \pm 0.01$ & $3.54^{\mathrm{a}} \pm 0.01$ & $7.78^{\mathrm{a}} \pm 0.03$ \\
\hline F1 & $23.34^{\mathrm{a}} \pm 0.01$ & $3.54^{\mathrm{a}} \pm 0.02$ & $7.78^{\mathrm{a}} \pm 0.03$ \\
\hline F2 & $23.36^{\mathrm{a}} \pm 0.01$ & $3.62^{\mathrm{b}} \pm 0.02$ & $7.84^{\mathrm{ab}} \pm 0.04$ \\
\hline F3 & $23.36^{\mathrm{a}} \pm 0.04$ & $3.61^{\mathrm{b}} \pm 0.01$ & $7.89^{\mathrm{bc}} \pm 0.03$ \\
\hline F4 & $23.37^{\mathrm{a}} \pm 0.01$ & $3.62^{\mathrm{b}} \pm 0.03$ & $7.86^{\mathrm{ab}} \pm 0.04$ \\
\hline F5 & $23.36^{\mathrm{a}} \pm 0.01$ & $3.65^{\mathrm{b}} \pm 0.02$ & $7.95^{\mathrm{c}} \pm 0.03$ \\
\hline
\end{tabular}

Data represented are mean \pm standard deviation of three independent experimental runs. Different alphabets in column represent significant difference at $\mathrm{P}<0.05$ using Tukey test 
Table.4 Water activity (aw) of brownies

\begin{tabular}{|c|c|}
\hline Formulations & $\mathbf{a}_{\mathbf{w}}$ \\
\hline Control & $0.7856^{\mathrm{b}} \pm 0.0030$ \\
\hline F1 & $0.7782^{\mathrm{a}} \pm 0.0003$ \\
\hline F2 & $0.7784^{\mathrm{a}} \pm 0.0002$ \\
\hline F3 & $0.7776^{\mathrm{a}} \pm 0.0002$ \\
\hline F4 & $0.7765^{\mathrm{a}} \pm 0.0004$ \\
\hline F5 & $0.7759^{\mathrm{a}} \pm 0.0004$ \\
\hline
\end{tabular}

Data represented are mean \pm standard deviation of three independent experimental runs. Different alphabets in column represent significant difference at $\mathrm{P}<0.05$ using Tukey test

Table.5

\begin{tabular}{|l|c|c|c|c|c|}
\hline Formulations & Protein (\%) & $\begin{array}{c}\text { Crude Fat } \\
(\mathbf{\%})\end{array}$ & Ash (\%) & $\begin{array}{c}\text { Crude fibre } \\
(\%)\end{array}$ & $\begin{array}{c}\text { Total } \\
\text { Carbohydrate }(\boldsymbol{\%})\end{array}$ \\
\hline Control & $12.6^{\mathrm{c}} \pm 0.265$ & $13.2^{\mathrm{a}} \pm 0.252$ & $1.27^{\mathrm{a}} \pm 0.252$ & $2.7^{\mathrm{a}} \pm 0.2$ & $45.6^{\mathrm{d}} \pm 0.38$ \\
\hline F1 & $11.7^{\mathrm{b}} \pm 0.208$ & $13.9^{\mathrm{b}} \pm 0.153$ & $3.23^{\mathrm{b}} \pm 0.153$ & $2.9^{\mathrm{a}} \pm 0.15$ & $42.4^{\mathrm{c}} \pm 0.1$ \\
\hline F2 & $11.5^{\mathrm{b}} \pm 0.2$ & $14.4^{\mathrm{c}} \pm 0.115$ & $4.5^{\mathrm{c}} \pm 0.2$ & $3.4^{\mathrm{b}} \pm 0.2$ & $39.8^{\mathrm{b}} \pm 0.95$ \\
\hline F3 & $11.5^{\mathrm{b}} \pm 0.305$ & $14.43^{\mathrm{c}} \pm 0.252$ & $5.6^{\mathrm{d}} \pm 0.1$ & $3.5^{\mathrm{b}} \pm 0.1$ & $39.0^{\mathrm{ab}} \pm 0.666$ \\
\hline F4 & $10.7^{\mathrm{a}} \pm 0.153$ & $14.6^{\mathrm{cd}} \pm 0.058$ & $6.1^{\mathrm{e}} \pm 0.2$ & $3.4^{\mathrm{b}} \pm 0.3$ & $38.7^{\mathrm{ab}} \pm 0.153$ \\
\hline F5 & $10.3^{\mathrm{a}} \pm 0.153$ & $14.9^{\mathrm{d}} \pm 0.1$ & $7.4^{\mathrm{f}} \pm 0.173$ & $3.7^{\mathrm{b}} \pm 0.2$ & $38.2^{\mathrm{a}} \pm 0.608$ \\
\hline
\end{tabular}

Data represented are mean \pm standard deviation of three independent experimental runs. Different alphabets in column represent significant difference at $\mathrm{P}<0.05$ using Tukey test

Fig.1 Flavor

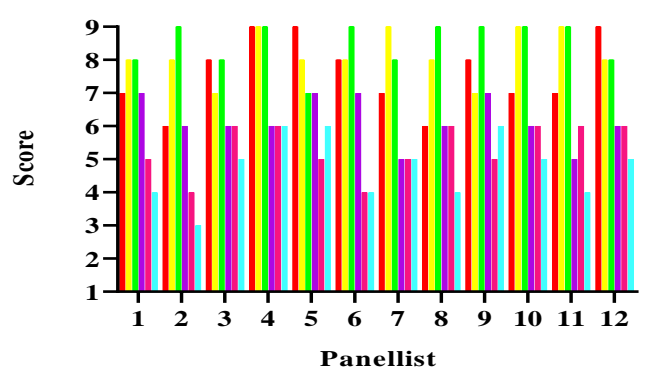

Fig.2 Color and appearance

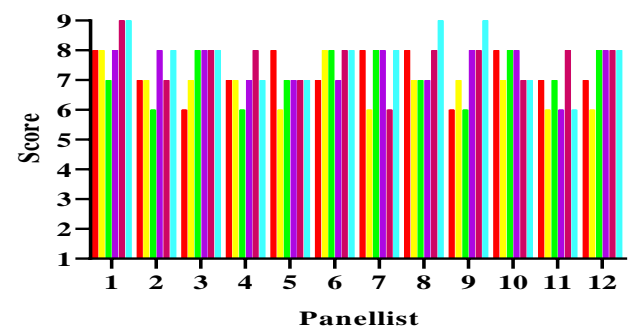


Fig.3 After taste

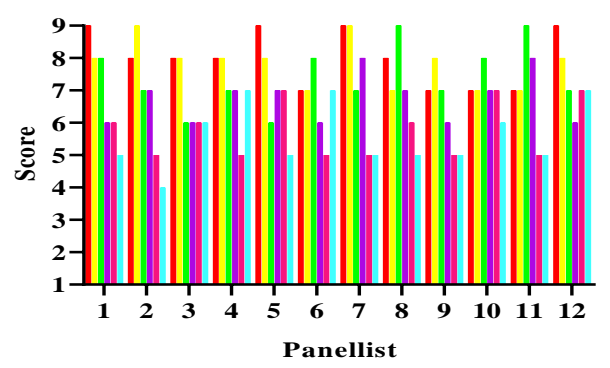

Fig.4 Mouth feel

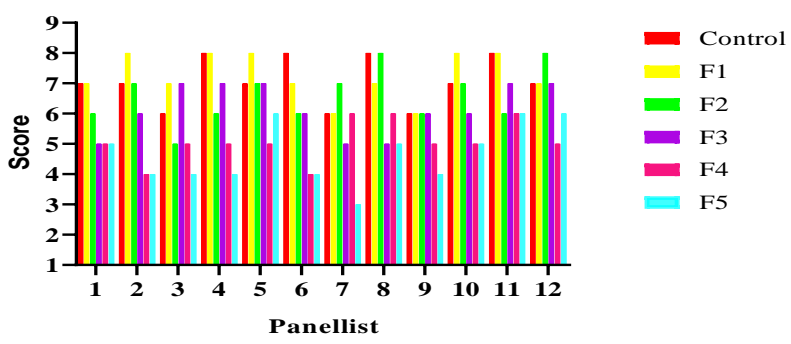

Fig.5 Overall acceptability

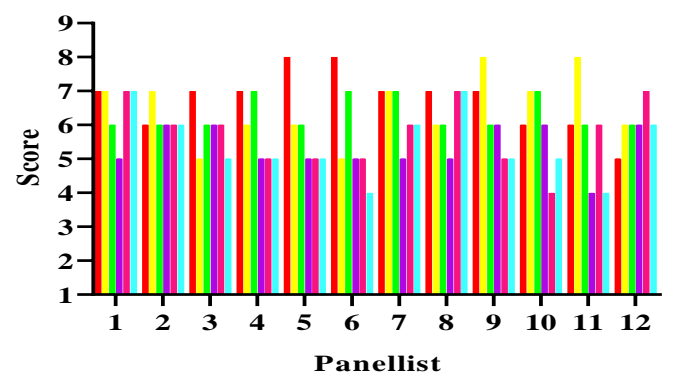

\section{Color and aw of the brownies}

Color values of brownie at different formulations were expressed in Table 3. The results showed that $\mathrm{L}^{*}$ value of the samples is not significantly different from the control where the $a^{*}$ and $b^{*}$ values were significantly different from the control ( $\mathrm{p}<0.05)$. This could be due to the certain amount of starch and protein present in the peel flour leads to the Maillard reaction and also chlorophyll degradation which is sensitive to higher temperature produces pheophytin and pheophorbide results in green brown color (Khoozani et al., 2019)

Table 4 shows the water activity of the brownies. Addition of banana peel flour in brownies decreased the water activity compared to control and showed significant difference $(\mathrm{p}<0.05)$. The lower water content in all formulations indicated greater stability and higher shelf life due to the lower rate of microbial growth and render superior stability against physical and chemical reactions (Menezes et al., 2011). 


\section{Proximate composition of brownies}

The proximate composition of the brownies prepared from banana peel and wheat flour blends is shown in Table 5. F1 had comparable protein content $(11.7 \%)$ with the control prepared with $100 \%$ wheat flour $(12.6 \%)$. This protein content was significantly higher than the other formulations when the level of the peel flour increased. This can act as a nutritional enhancement for the development of food products. The fat content increased from $13.2 \%$ to $13.9 \%$ which improves the flavor of the brownies. Ash content increased from $1.27 \%$ to $3.23 \%$ when the peel flour is added into the brownies. Crude fibre ascended from $2.7 \%$ to $2.9 \%$ due to the large amount of fibre content in the peel of banana. Increase in ash content is due to the availability of higher ash content in banana peel, whereas the carbohydrate content is higher in control than in other formulations.

\section{Sensory analysis of brownies}

A total of 12 members participated in the analysis including 6 men and 6 women between 20-30 years of age. Wheat brownie was preferred over the test samples in terms of color and appearance, flavor, mouth feel, after taste and overall acceptability and expressed in figures. The brownies containing $40 \%$ and $50 \%$ peel flour scored lowest with respect to other formulated brownies in all sensory attributes evaluated. In F4 and F5 the scores of every attribute were constantly reduced as the level of peel flour increased however the score of color and appearance were increased. This could be due to the enzymes present in the processed peel flour. Moreover, the overall acceptability and flavor of banana peel flour brownies reduced with the increased level of peel flour which provides bitter taste due to the presence of tannins (Akubor \& Ishiwu, 2013).
In conclusion the addition of Mysore $\mathrm{AAB}$ peel flour into wheat brownies formulation had considerable effects on the chemical, physical and sensory properties of the brownies. From the current research it can be stated that peel flour can be added into the wheat flour brownies up to $20 \%$ to produce brownies of improved nutritional quality with acceptable sensory attributes. Hence, the production and consumption of such products would also boost the nutritional status of the population. However, more research should be carried out to explore the possibility of using Mysore AAB banana peel flour as an ingredient in other food items in order to expand the use of such value-added food ingredient.

\section{Acknowledgement}

We would like to show our gratitude to the Indian Institute of Food Processing Technology for their support to this study.

\section{References}

Abreu, M. de, Alves, I., Eduardo, D. M., Asquieri, R., Jose, D., \& Damiani, C. (2020). Red mombin (Spondias purpurea L.) seed flour as a functional component in chocolate brownies. https://doi.org/10.1007/s13197-02004574-4

Amini Khoozani, A., Birch, J., \& Bekhit, A. E. D. A. (2019). Production, application and health effects of banana pulp and peel flour in the food industry. Journal of Food Science and Technology, 56(2), 548-559.

https://doi.org/10.1007/s13197-018$0356 z$

Carvalho, V. S., \& Conti-Silva, A. C. (2018). Cereal bars produced with banana peel flour: evaluation of accepatbility and sensory profile. J Sci Food Agric, 134139. https://doi.org/10.1002/jsfa.8447 
I, L., C, A., \& A, S. (2018). Physical, chemical and sensory properties of brownies substituted with sweet potato flour (Ipomoea batatas L.) with addition of black cumin oil (Nigella sativa L.)

Kitts, D. D. (1994). Bioactive substances in food: identification and potential uses. Canadian Journal of Physiology and Pharmacology.

Lee, E. H., Yeom, H. J., Ha, M. S., \& Bae, D. H. (2010). Development of banana peel jelly and its antioxidant and textural properties. Food Science and Biotechnology, 19(2), 449-455. https://doi.org/10.1007/s10068-0100063-5

Nasrin, T. A. A., Noomhorm, A., \& Anal, A. K. (2015). Physico-Chemical Characterization of Culled Plantain Pulp Starch, Peel Starch, and Flour. International Journalof Food Properties, 18(1),165-177. https://doi.org/10.1080/10942912.2013. 828747

Pathak, P. D., Mandavgane, S. A., \& Kulkarni, B. D. (2016). Valorization of banana peel: a biorefinery approach. https://doi.org/10.1515/revce-20150063

Zhang, P., Whistler, R. L., Bemiller, J. N., \& Hamaker, B. R. (2009). Banana starch: production, physicochemical properties, and digestibility - a review *. 59(2005), $\quad$ 443-458. https://doi.org/10.1016/j.carbpol.2004.1 0.014

Moraes, É. A., Dantas, M. I. de S., Morais, D. de C., Silva, C. O. da, Castro, F. A. F. de, Martino, H. S. D., \& Ribeiro, S. M. R. (2010). Sensory evaluation and nutritional value of cakes prepared with whole flaxseed flour. Ciência $e$ Tecnologia de Alimentos, 30(4), 974 979. https://doi.org/10.1590/s010120612010000400021

Marina Lisboa Silva, Luciana Gama de
Mendonça, Rafael Audino Zambelli, Ana Lídia Martins Magalhães, Cristiano Silva da Costa, Marcos Venânces De Souza Leão, R. de A. R. de S. C. (2017). Impact of Green Pulp Banana and Flaxseed Flour on Pound Cake Quality. International Journal of Nutrition and Food Sciences, 6(6), 243249.

Mohamed, A., Xu, J., \& Singh, M. (2010). Yeast leavened banana-bread: Formulation, processing, colour and texture analysis. Food Chemistry, 118(3), 620-626. https://doi.org/10.1016/j.foodchem.2009 .05 .044

Khoozani, A. A., Bekhit, A. E. A., \& Birch, J. (2019). International Journal of Biological Macromolecules Effects of different drying conditions on the starch content, thermal properties and some of the physicochemical parameters of whole green banana flour. International Journal of Biological Macromolecules, 130, 938-946.

https://doi.org/10.1016/j.ijbiomac.2019. 03.010

Menezes, E. W., Tadini, C. C., Tribess, T. B., Zuleta, A., Binaghi, J., Pak, N., Vera, G., Dan, M. C. T., Bertolini, A. C., Cordenunsi, B. R., \& Lajolo, F. M. (2011). Chemical Composition and Nutritional Value of Unripe Banana Flour (Musa acuminata, var. Nanicão). Plant Foods for Human Nutrition, 66(3), 231-237. https://doi.org/10.1007/s11130-0110238-0

Sandra, Prayogi, I. Y., Damayanti, R., \& Djoyowasito, G. (2020). Design to prediction tools for banana maturity based on image processing. IOP Conference Series: Earth and Environmental Science, 475(1). https://doi.org/10.1088/17551315/475/1/012010 
Kumar, S. P., A, S., N, S., \& S, U. (2019). Functional and physiochemical properties of green banana flour from dessert and plantain bananas (Musa spp.). LWT - Food Science and Technology.

Theagarajan, R., Malur Narayanaswamy, L., Dutta, S., Moses, J. A., \& Chinnaswamy, A. (2019). Valorisation of grape pomace (cv. Muscat) for development of functional cookies. International Journal of Food Science and Technology, 54(4), 1299-1305. https://doi.org/10.1111/ijfs.14119

P I, Akubor., \& Ishiwu, C. (2013). Chemical composition, physical and sensory properties of cakes supplemented with plantain peel flour. 1(June), 87-92.

AOAC International (2016). Official Methods of Analysis, 20th edn. (On-line). Rockville, MD: AOAC International.

FAOSTAT, D. (2017). Food and agriculture organization of the United Nations. Statistical database.

\section{How to cite this article:}

Divya, C., Ammiti Sheeba Rani, M. Tito Anand, N. Baskaran and Vidyalakshmi, R. 2021. Substituting Wheat Flour using Banana Peel Flour to Enhance the Nutritional Characteristics of Brownies. Int.J.Curr.Microbiol.App.Sci. 10(01): 3583-3591. doi: https://doi.org/10.20546/ijcmas.2021.1001.423 